\title{
Assessing Residents' Satisfaction with Planning and Neighbourhood Facilities of Some Public Housing Estates in Benin City, Nigeria
}

\author{
Kingsley Okechukwu Dimuna \\ Department of Architecture, \\ Ambrose Alli University, \\ Ekpoma, Nigeria
}

\section{Abiodun Olukayode Olotuah}

Department of Architecture, Federal University of Technology, Akure, Nigeria

Doi: 10.2478/jesr-2019-0002

\begin{abstract}
The objective of the study is to analytically assess the residents' perception of planning of six housing estates and their satisfaction levels in Benin City, Edo state, Nigeria. The population of the study comprises all residents of the six housing estates in Benin City as at 2018 which is the study period. The data were collected from the six (6) estates covered by this study: Oluku Housing Estate, EDPA Housing Estates Ugbowo, Federal Housing Estate, Oregbeni, Federal Housing Estate on Ikpoba Hill, lyekogba Housing Estate, Ebo Village, and Andrew Wilson Housing Estate, Evbuoriaria. A total of 1200 copies of questionnaires were administered across the six housing estates. However, the total response rate of 1000 was achieved as only these copies of questionnaires were retrieved in usable format. Descriptive statistical tools such as means, standard deviations, kruskal-willis test and categorical regression analysis were utilized for the data analysis. The result showed that the relative satisfaction index scores for the all the estates are on the fairly satisfied region (RSI: 2.1-3.0) and this implies that residents are fairly satisfied with the estate planning conditions. The Kruskal-willis test confirms the absence of any significant differences in RSI scores across the estates while the categorical regression analysis results shows that estate planning has a positive effect on residents satisfaction and this is significant at $5 \%$ $(p=0.003)$ which implies improvement in estate planning results in higher satisfaction levels. The study recommends the need for Government policy to encourage a decent living environment in terms of planning of estates.
\end{abstract}

Keywords: housing, planning, public, neighbourhood, residents, satisfaction

\section{Introduction}

Housing is essential for human existence as it is one of the top three needs of man. Its provision has always been of great necessity to man (Olotuah \& Taiwo, 2013, Olotuah \& Ajayi, 2008). Chukwujekwu (2005) has shown that housing at different times, has remained a strategic asset to man irrespective of his socio-economic status, colour, or creed. As a unit of the environment, housing has profound influences on the health, efficiency, social behaviour, satisfaction and general welfare of the community (Osuide, 2004; Olotuah, 1997). Housing and residential quality and the satisfaction one derives from them are particularly important. 
Residential and neighbourhood satisfaction is an important indicator of housing quality and conditions, which affects the individual's quality of life (Olatubara \& Fatoye, 2007; Adriaanse, 2007; Kellekc \& Berkoz, 2006; Dimuna, 2017). Housing satisfaction refers to the degree of contentment experienced by an individual or family with regard to the current housing situation (Djebarni \& AlAbed, 2000). In order to enhance the quality of life, promote greater community participation and social integration of the population, it is necessary to provide adequate, quality housing and well organised urban services. Gbakeji (2014) has shown that in order to satisfy residents, a residential environment must symbolize desirable aspects of the wider social world, since how much residential locations are identified with would depend on whether one's living space meets the social needs while reflecting and maintaining one's status.

Virtually everyone tries to achieve as satisfactory a residential environment as possible, subject to the constraints of class and life-cycle stage. Within broad limits of income and family lifecycle stage, however, there are many other factors that determine residential satisfaction, especially in the wider context of the neighbourhood (Vrbka \& Combs, 1991; Ajanlekoko, 2001; Nwaka, 2005; Akinmoladun \& Oluwoye, 2007). Housing or residential satisfaction essentially evaluates residents' perceptions of and feeling for their housing units and surrounding environment; suggesting that the two are interchangeable concepts that serve the same purpose in housing research (Ogu, 2002; Galster, 1987; Ramdane and Abdullah, 2000)

Public sector intervention in housing in Nigeria began in the colonial era with the clearance of the bubonic plague in Lagos. Government efforts were concentrated on building of staff quarters for expatriate workers and specialized institutions like the Railways, and the construction of buildings in Government Reservation Areas. In the 1970s strategies of public sector intervention changed to the direct construction of houses for the populace particularly the low-income category.

Consequently, the following public housing estates were provided by both the State and Federal Governments in Benin City. They are:

i. Ikpoba Hill Housing Estate

ii. Iguosa Housing Estate

iii. Oregbeni Housing Estate

iv. EDPA Housing Estate, Ugbowo

v. Andrew Wilson Housing Estate, Evboriaria, and

vi. lyekogba Housing Estate.

The quality of these housing estates and the perception of residents in terms of housing satisfaction need to be examined. This paper, therefore, investigates the level of residential satisfaction with the planning and neighbourhood facilities of the six (6) public housing estates in Benin City, Edo state, Nigeria; with a view to examining their functionality and adequacy of facilities provided in the housing estates.

\section{The Study Area}

The study area is Benin City, the capital of Edo State of Nigeria. The city comprises three local governments' areas of: Oredo, Egor, and Ikpoba Okha, which make up the Benin Metropolis. Benin City is one of the major urban centres in Nigeria. It is a pre-colonial city and its urban history dates back to the $7^{\text {th }}$ century B.C. But urbanization has stretched the city towards Oluku in Ovia North East and Eyaen in Uhumwunde Local Government Areas. This study is concerned with some public housing estates such as Ikpoba Hill, Ugbowo, Oregbeni, Iguosa, Andrew Wilson (Evboriaria) and lyekogba Housing Estates.

Geographically, Benin City lies within the latitude $6^{\circ} 20^{1}$ and $6^{\circ} 31^{1}$ North and longitude $5^{\circ} 32^{1}$ and $5^{\circ} 41^{1}$ East of the Greenwich meridian. Benin City has grown in landmass from an area size of 949 hectares in 1952, to 2217.6 hectares in 1963 census, to 16800.0 hectares in 1991 census and 19,794 hectares in 2006 census (National Population Census, NPC, 2006.) 


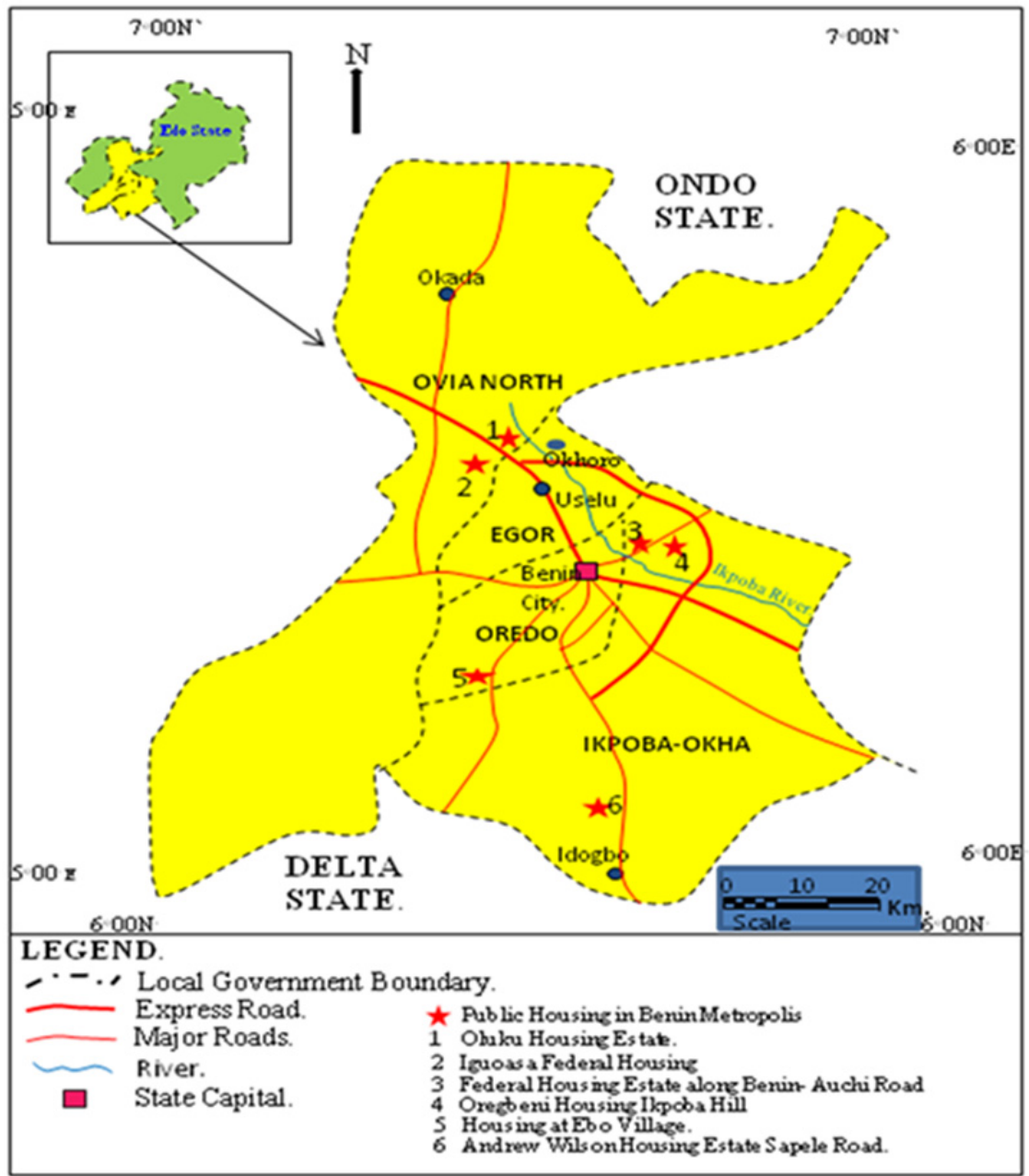

Figure 1: Location of Public Housing in Benin City Source: Cartography Studio, A. A. U. Ekpoma, 2014

The population of Benin City was given as 53,753 in 1952 census and 100,693 by 1963 census. However, the population of the city in the 1991 census was given as 780,976 persons (National Population Commission, 1991). But using a population growth of $3.1 \%$; the population of Benin City in 2005 was estimated at 1,161,117.9; but the 2006 census recorded the population of the city to be $1,346,703$. Using a population growth of $3.1 \%$; the population of Benin City in 2015 was estimated at $1,719,258.4$. This population growth, no doubt reflects a dynamic urban centre with lots of pressure on housing provisions and invariably housing quality and standard.

\section{Methodology}

Data was obtained from both primary and secondary sources. The primary sources of data were from observations, focus group discussions, and oral interviews, administration of structured questionnaires made during visits to the residents of Public Housing Estates. The study adopted the multiple case studies strategy in developing an understanding of the differences among the 
housing estates in the study areas as suggested by Yin (2009). The study examined six completed and occupied housing estates in Benin City, namely the Federal Housing Estates at Ikpoba Hill and Iguosa, and state-owned housing estates located at Ugbowo, Oregbeni, Oluku, Andrew WilsonEvboriaria, and lyekogba. Data from the fieldwork were generated from structured and semistructured questionnaires administered to the residents and other stakeholders. For this study, comprehensive data on residents' levels of satisfaction with public housing estate was required. Consequently, a field survey was carried out to obtain primary data. The data was obtained from visits to the six estates used as case study for the research. Basically, data collection was done using the random sampling technique. A total of 1200 copies of a questionnaire were administered across the six (6) estates covered. However, the administration of the questionnaire was based on the number of housing units in each estate. All housing units in the estates covered were numbered and the housing units falling on the odd numbers were selected. A combination of statistical tools was used in the analysis of the data. A regression analysis was used to examine the explanatory variables of residents' housing satisfaction and to test the research hypothesis

\section{Presentation and Analysis of Result}

Table 1 shows the breakdown of the demographic information of respondents. The gender distribution shows the number of males and females in the estates. Specifically, for lyekogba (Male $=66 \%$, Female $=34 \%$ ), Ikpoba hill (Male $=60 \%$, female $=40 \%$ ), for Andrew Wilson ( $\mathrm{male}=69 \%$, female $=31 \%$, for EDPA (male $=72 \%$, female $=28 \%$ ), for Oregbeni (male $=55.50 \%$, female $=44.50 \%$ ) and for Oluku (male $=69 \%$, female $=31 \%$ ). The table 1 also shows the age distribution for residents in the estates. As observed, the number of resident less than 30 years have the lowest representation across the following estates, lyekogba (11\%), Ikpoba hill (13\%), Andrew Wilson $(3 \%)$, for EDPA $(15.50 \%)$, Oregbeni $(8 \%)$ and for Oluku $(3 \%)$. Those between $31-45$ years are more in Oluku estate (46\%) and Andrew Wilson (46\%). Residents between ages 60- above appear to be more in Oregbeni $(42 \%)$ and followed by Ugbowo $(24 \%)$. The educational qualification of resident in the estates reveals that residents with $1^{\text {st }}$ degree are highest for EDPA (38\%). Residents with SSCE appear to be highest for Oregbeni (52\%), followed by Ikpoba-hill (50\%) incidentally, these estates are also part of the oldest. Residents with post-graduate degree appear to be highest for EDPA (32\%). Also, data on the type of occupancy of residents showed that owner-occupier for lyekogba (61\%), Ikpoba hill (78\%), Andrew Wilson (68\%), for EDPA (66\%), Oregbeni $(73 \%)$ and for Oluku (68\%) while for tenant-occupier the statistics are; lyekogba (39\%), Ikpoba hill (22\%), Andrew Wilson (32\%), for EDPA (34\%), Oregbeni $(27 \%)$ and for Oluku $(32 \%)$. It is important to note however that though most of the housing units were allotted on an owner-occupier basis, most of the original owners have rented or leased these units to other individuals.

Table 1: Respondents' socio-economic characteristics

\begin{tabular}{|c|c|c|c|c|c|c|}
\hline Estate & lyekogba & Ikpoba hill & Andrew Wilson & EDPA Ugbowo & Oregbeni & Oluku \\
\hline & $n=100$ & $n=200$ & $n=100$ & $n=200$ & $n=200$ & $\mathrm{n}=200$ \\
\hline \multicolumn{7}{|l|}{ (a). Gender } \\
\hline \multirow[t]{2}{*}{ Male } & 66 & 120 & 69 & 144 & 111 & 138 \\
\hline & $66 \%$ & $60 \%$ & $69 \%$ & $72 \%$ & $55.50 \%$ & $69 \%$ \\
\hline \multirow[t]{2}{*}{ Female } & 34 & 80 & 31 & 56 & 89 & 62 \\
\hline & $34 \%$ & $40 \%$ & $31 \%$ & $28 \%$ & $44.50 \%$ & $31 \%$ \\
\hline \multicolumn{7}{|l|}{ (b). Age } \\
\hline \multirow[t]{2}{*}{$<30$} & 11 & 26 & 3 & 31 & 16 & 6 \\
\hline & $11 \%$ & $13 \%$ & $3 \%$ & $15.50 \%$ & $8 \%$ & $3 \%$ \\
\hline \multirow[t]{2}{*}{$31-45$} & 30 & 54 & 46 & 49 & 50 & 92 \\
\hline & $30 \%$ & $27 \%$ & $46 \%$ & $24.50 \%$ & $25 \%$ & $46 \%$ \\
\hline \multirow[t]{2}{*}{$46-59$} & 40 & 84 & 39 & 72 & 50 & 78 \\
\hline & $40 \%$ & $42 \%$ & $39 \%$ & $36 \%$ & $25 \%$ & $39 \%$ \\
\hline \multirow{2}{*}{60 -above } & 19 & 36 & 12 & 48 & 84 & 24 \\
\hline & $19 \%$ & $18 \%$ & $12 \%$ & $24 \%$ & $42 \%$ & $12 \%$ \\
\hline
\end{tabular}




\begin{tabular}{|c|c|c|c|c|c|c|}
\hline Estate & lyekogba & Ikpoba hill & Andrew Wilson & EDPA Ugbowo & Oregbeni & Oluku \\
\hline & $n=100$ & $n=200$ & $n=100$ & $n=200$ & $n=200$ & $n=200$ \\
\hline \multicolumn{7}{|l|}{ (c) Education } \\
\hline \multirow[t]{2}{*}{ SSCE } & 24 & 100 & 19 & 28 & 104 & 38 \\
\hline & $24 \%$ & $50 \%$ & $19 \%$ & $14 \%$ & $52 \%$ & $19 \%$ \\
\hline \multirow[t]{2}{*}{ OND/NCE } & 36 & 61 & 31 & 32 & 69 & 62 \\
\hline & $36 \%$ & $30.50 \%$ & $31 \%$ & $16 \%$ & $34.50 \%$ & $31 \%$ \\
\hline \multirow[t]{2}{*}{ 1st degree } & 33 & 30 & 36.5 & 76 & 18 & 73 \\
\hline & $33 \%$ & $15 \%$ & $36.5 \%$ & $38 \%$ & $9 \%$ & $36.5 \%$ \\
\hline \multirow[t]{2}{*}{ Post-graduate } & 7 & 9 & 13.5 & 64 & 9 & 27 \\
\hline & $7 \%$ & $4.50 \%$ & $13.5 \%$ & $32 \%$ & $4.50 \%$ & $13.50 \%$ \\
\hline \multicolumn{7}{|c|}{ (f). Type of occupancy } \\
\hline \multirow[t]{2}{*}{ Owner occupier } & 61 & 156 & 68 & 132 & 146 & 136 \\
\hline & $61 \%$ & $78 \%$ & $68 \%$ & $66 \%$ & $73 \%$ & $68 \%$ \\
\hline \multirow[t]{2}{*}{ Tenant Occupier } & 39 & 44 & 32 & 68 & 54 & 64 \\
\hline & $39 \%$ & $22 \%$ & $32 \%$ & $34 \%$ & $27 \%$ & $32 \%$ \\
\hline
\end{tabular}

Source: Field survey (2018).

The table 2 shows the relative satisfaction index (RSI) and descriptive statistics. As observed, the RSI for Proximity to religious center (PRC) is 2.61, Good Location of Building (GLB)= 2.782, Good site layout (GSL) is2.713, Good access to building (GAB) is 2.674, Availability of parking lots(APL) is 2.774, Availability of public transport(APT) is 2.736, Play area for children (PAC) is 2.9503 , Closeness of shopping facilities (CSF) is 2.852, Landscaping (LSS) is 2.15, Nearness to health facilities $(N H F)=2.715$, Good site layout (GSL) is 2.718 . In evaluating the level of satisfaction of residents using the six distinct estates, the relative satisfaction index scores are observed. For estate planning dimension the result showed that the RSI scores for the all the estates are on the fairly satisfied region (RSI: 2.1-3.00) and this implies that residents are fairly satisfied with the estate planning conditions. The Mean Average Score (MAS) values for the variables are as follows; Proximity to religious centre (PRC) is 3.39, Good Location of Building (GLB) is 3.218 , Good site layout (GSL) is 3.287 , Good access to building (GAB) is 3.326 , Availability of parking lots (APL) is 3.213 and Closeness of shopping facilities (CSF) is 3.285 . The value gives an indication of the average clustering of the responses to each statement. The value of Cronbach alpha ranges between 0 and 1 and the higher the value the higher the internal consistency between the scale items. Nunnally (1979) has recommended 0.7 as a satisfactory measure of internal consistency. As observed the cronbach alpha for all the variables are above 0.70 and this confirms the reliability of the concepts and that they indeed measure what was intended in the study.

Table 2: Aggregate Relative satisfaction index scores and Descriptive statistics

\begin{tabular}{|l|c|c|c|c|c|c|}
\hline & RSI & MS Mean Score & $\begin{array}{c}\text { Standard } \\
\text { Error }\end{array}$ & $\begin{array}{c}\text { Standard } \\
\text { deviation }\end{array}$ & $\begin{array}{c}\text { Normality } \\
\text { Test }\end{array}$ & $\begin{array}{c}\text { Cronbach } \\
\text { Alpha }\end{array}$ \\
\hline Estate planning & & & & & & 0.986 \\
\hline Proximity to religious centre (PRC) & 2.61 & 3.39 & 0.02232 & 0.70597 & 33.77 & \\
\hline Good Location of Building (GLB) & 2.782 & 3.218 & 0.03267 & 1.03322 & 53.07 & \\
\hline Good site layout (GSL) & 2.713 & 3.287 & 0.03098 & 0.97959 & 69.28 & \\
\hline Good access to building (GAB) & 2.674 & 3.326 & 0.03047 & 0.96367 & 83.63 & \\
\hline Availability of parking lots(APL) & 2.774 & 3.213 & 0.03697 & 1.16919 & 93.47 & \\
\hline Availability of public transport(APT) & 2.736 & 3.226 & 0.03347 & 1.05832 & 100 & \\
\hline Play area for children(PAC) & 2.950 & 3.264 & 0.03045 & 0.96293 & 38.353 & \\
\hline Closeness of shopping facilities (CSF) & 2.852 & 3.285 & 0.0307 & 0.97094 & 55.924 & \\
\hline Landscaping (LSS) & 2.15 & 3.85 & 0.01969 & 0.62281 & 70.188 & \\
\hline Nearness to health facilities(NHF) & 2.715 & 3.148 & 0.02951 & 0.93326 & 81.126 & \\
\hline Good site layout (GSL) & 2.718 & 3.05 & 0.03673 & 1.1614 & 91.488 & \\
\hline
\end{tabular}

Source: Field survey (2018). 
Table 3 shows the factor analysis results for the study. Factor analysis is a key multi-variate analytical technique when dealing with data especially of this sort. The technique provides a basis for investigating if the variables properly define the underlying construct. The technique is important as dimension reduction is one of the major tasks for multivariate analysis. The KMO and Bartlett sphericity test confirms that the factor analysis is suitable for the study. As observed the factor loadings and \% variance of each item under Estate planning are as follows; for Good site layout $(G S L)=\{0.931,90.263\}$, Proximity to religious centre $(P R C)=\{0.978,1.647\}$, Good Location of Building $(\mathrm{GLB})=\{0.98,4.067\}$, Good access to building $(\mathrm{GAB})=\{0.978,0.976\}$, Availability of parking lots $(A P L)=\{0.985,0.854\}$, Availability of public transport $(A P T)=\{0.811,0.792\}$, Play area for children $(P A C)=\{0.953,0.511\}$, Closeness of shopping facilities $(C S F)=\{0.948,0.426\}$, Landscaping (LSS) $=\{0.9840 .282\}$, Nearness to health facilities(NHF) $=\{0.928,0.096\}$ and Good site layout $(G S L)=\{0.96,0.085\}$. From the analysis of the statistics, all items load significantly into the factor as their loading values are greater than 0.5 and this suggest that all items describe quite strongly the concept of estate planning. However, Good site layout (GSL) appears to account for the highest \% variance and this suggest that this factor is considered very highly in terms of the design of estates.

Table 3. Factor Analysis

\begin{tabular}{|l|c|c|c|c|c|c|}
\hline & Factor loading & Eigen value & $\%$ variance & Cum\% & KMO & $\begin{array}{c}\text { Bartlett } \\
\text { Sphericity }\end{array}$ \\
\hline Estate planning & & & & & 0.941 & 0.00 \\
\hline Good site layout (GSL) & 0.931 & 9.929 & 90.263 & 90.263 & & \\
\hline Good Location of Building (GLB) & 0.98 & 0.447 & 4.067 & 94.33 & & \\
\hline Proximity to religious centre (PRC) & 0.978 & 0.181 & 1.647 & 95.977 & & \\
\hline Good access to building (GAB) & 0.978 & 0.107 & 0.976 & 96.953 & & \\
\hline Availability of parking lots(APL) & 0.985 & 0.094 & 0.854 & 97.808 & & \\
\hline Availability of public transport(APT) & 0.811 & 0.087 & 0.792 & 98.6 & & \\
\hline Play area for children(PAC) & 0.953 & 0.056 & 0.511 & 99.111 & & \\
\hline Closeness of shopping facilities (CSF) & 0.948 & 0.047 & 0.426 & 99.537 & & \\
\hline Landscaping (LSS) & 0.984 & 0.031 & 0.282 & 99.819 & & \\
\hline Nearness to health facilities(NHF) & 0.928 & 0.011 & 0.096 & 99.915 & & \\
\hline Good site layout (GSL) & 0.963 & 0.009 & 0.085 & 100 & & \\
\hline
\end{tabular}

Source: Field survey (2018).

Table 4 shows the Kruskal-Wallis test is used to test for differences between more than two independent groups. This test is the non-parametric alternative of the Analysis of Variance (ANOVA) for ordinal variables and it converts the scores on the continuous variable to ranks across the groups. The statistics is used to examine if significant differences exist in satisfaction levels across the estates. The Kruskal-Wallis test statistics shows that significant differences do not exist across the estates.

Table 4: Kruskal-Wallis Test of Differences in Resident's Satisfaction

\begin{tabular}{|l|c|}
\hline Estate planning \\
\hline Kruskal Wallis Test \\
\hline Kruskal Wallis Test & 7.577 \\
\hline Df & 4 \\
\hline Asymp. Sig. & .099 \\
\hline
\end{tabular}

Source: SPSS 20.0

Table 5 shows the Categorical Regression Analysis (CATREG) used to investigate of significant relationship exists between estate planning and the residents satisfaction levels. The ANOVA 
results indicates that for the $f$-stat of 99.288 it is significant at $5 \%(p=0.00)$ which suggests that Estate planning significantly affects variations in Residents satisfaction. As observed, the coefficient of determination $\left(R^{2}\right)=0.710 \%, \operatorname{Adj} R^{2}=0.700 \%$. These values suggest that the regression model explains about $71.0 \%$ of residual variations in Resident satisfaction with an adjusted value of $70.0 \%$ after controlling for degrees of freedom. The beta of 0.7788 shows that estate planning has a positive effect on residents satisfaction and this is significant at $5 \% \quad(p=0.003)$ which implies improvement in estate planning results in higher satisfaction levels. Since the $P$. value is $<0.05$, the study rejects the null hypothesis $\left(\mathrm{H}_{0} 1\right)$, no significant relationship between Estate Planning and residents' satisfaction. This finding is in agreement with Moughalu (1986), Ukoha and Beamish (1997).

Table 5: Categorical Regression between RSI and Estate planning

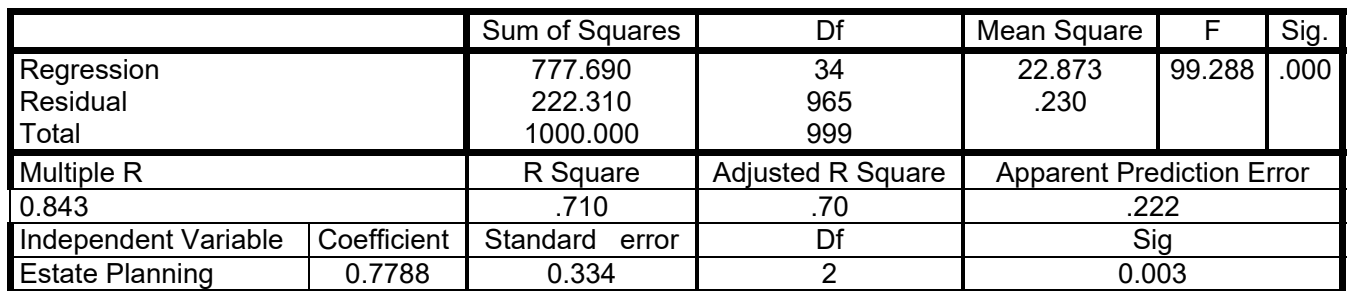

Source: Field study, 2018. Dependent Variable: RSI, Predictor: Estate planning

\section{Conclusion}

The finding of the study indicated that the planning of the estates significantly affects the level of residents' satisfaction. The study revealed that residents were fairly satisfied in the components of estates planning such as proximity to religious centres, site layout, access to building, availability of parking lots, availability of children play ground, nearness to shopping and health centres. Government policy should thus encourage a decent living environment in terms of planning of estates. In order to effectively provide housing that satisfies the low-income earner, every effort should be made to study and understand the life style of this class of people.

\section{References}

Adriaanse, C. C. M. (2007). Measuring residential satisfaction: a residential environmental satisfaction scale (RESS). Journal of Housing Build Environment, 22(2) 287-304

Ajanlekoko, K. S. (2001).Sustainable housing development in Nigeria-The financial and infrastructural implication. Paper presented at the International Conference on Spatial Information for Sustainable Development in Nairobi, Kenya, 2-5 October2001. Available online http://www.fig.net/pub/proceeding/nairobi/ajanlekoko. Retrieved on July 13, 2007.

Akinmoladun, O.I., \& Oluwoye, J., (2007). An assessment of why the problems of housing shortages persist in developing countries: a case of study of Lagos Metropolis, Nigeria. Pakistan Journal of Social Science 4(4) 589-598.

Dimuna, K.O. (2017). A study of residents' satisfaction with public low-cost housing estates in Benin City, Edo State, Nigeria. Unpublished PhD Thesis submitted to School of Postgraduates Studies, Ambros Alli University, Ekpoma, Edo State, Nigeria.

Djebarni, R. and Al-Abed, A. (2000). Satisfaction level with neighbourhoods in low-income public housing in Yemen. Property Management, 18(4): 230-239.

Galster .G. (1987).Identifying the correlates of dwelling satisfaction: An empirical critique. Environment and Behaviour 19(5):735-568

Gbakeji, J.O. (2014): Analysis of residential Satisfaction in some residential neighbourhood in Benin City, Nigeria. Journal of Civil and Environmental Engineering, 2(1) 1-10

Kellekc, O. L. \& Berkoz, L, (2006). Mass housing: Users satisfaction in housing and its environment in istanbul. European Journal of Housing Policy, 6(1), pp.77-99. 
Moughalu, L.N. (1986). A comparative evaluation of residents' satisfaction with public and private rental housing in Benin City. Unpublished PhD Thesis submitted to the Department of Geography and Regional Planning. University of Benin.

National Population Commission (1991). Population and housing census of the federal republic of Nigeria

National Population Commission (2006). Population and housing census of the Federal Republic of Nigeria priority tables (vol. 1)

Nunnally L. (1979). Cronbach alpha statistics: retrieved from www.ssrn.com on $31^{\text {st }}$ May, 2018

Nwaka, G.I. (2005). The urban informal sector in Nigeria: towards economic development, environmental health and social Harmony. Global Urban Development Magazine, 1(1). Available Online at http://www.globalurban.org/issue 1PImag05/Nwakaarticle.htm. Accessed on March 26,

Ogu, V. I, (2002). Urban residential satisfaction and the planning implications in a developing world context: the example of Benin City, Nigeria. International. Planning Studies, (7):37-53.

Olatubara, C. O. \& Fatoye, E. O. (2007). Evaluation of the satisfaction of occupants of the abesan public lowcost housing estate in Lagos State, Nigeria. The Nigerian journal of Economic and Social Studies 49 (1).

Olotuah, A. O. (1997) "The House: Accessibility and Development - A Critical Evaluation of the Nigerian Situation" In The House in Nigeria, Proceedings of the National Symposium, Bayo Amole (Ed.) Obafemi Awolowo University lle - Ife, Nigeria, 23-24 July, 312 - 317

Olotuah, A.O. and Ajayi, M. A. (2008): "Repositioning Women in Housing Development" Indian Journal of Gender Studies, 15 (1) 101- 113. DOI: 10.1177/097152150701500105, EID: 2-s2.0-69849125960. http://ijg.sagepub.com/content/15/1.toc

Olotuah, A. O. and Taiwo, A. A. (2013): "Housing the Urban Poor in Nigeria through Low-Cost Housing Schemes "International Journal of Physical and Human Geography, 1, 1-8

Osuide S. O. (2004). Strategies for affordable housing stock delivery in Nigeria. $18^{\text {th }}$ Inaugural Lecture Series, Ambrose Alli University, Ekpoma. February 2004, P.1.

Ramdane, D. \& Abdullah, A. A. (2000) Satisfaction level with neighbourhoods in low-income public housing in Yemen. Property Management, 18(4), 230

Ukoha, O.M. and Beamish, J.O (1997) Assessment of residents' satisfaction with public housing in Abuja, Nigeria. Habitat International 21(4) 445-460.

Vrbka, S. J. \& Combs, E. R. (1991). Predictors of neighbourhood and community satisfaction in Rural Communities. Referred papers of the American Association of Housing Educators Annual Conference, Durham, NH.

Yin, R.K. (2008) Case Study Research: Design and Methods (3rd edition), Thousand Oaks, CA; Sage 